Taxonomy and systematics

\title{
Three new harvestman species of the genus Philora (Opiliones: Gonyleptoidea: Stygnopsidae) with comments on troglomorphisms
}

\section{Tres especies nuevas del género Philora (Opiliones: Gonyleptoidea: Stygnopsidae) con comentarios sobre troglomorfismos}

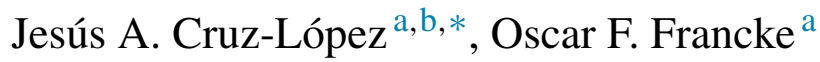 \\ ${ }^{a}$ Colección Nacional de Arácnidos, Departamento de Zoología, Instituto de Biología, Universidad Nacional Autónoma de México, Apartado postal 70-153, \\ 04510 Ciudad de México, Mexico



Received 20 October 2015; accepted 19 February 2016

Available online 24 May 2016

\begin{abstract}
Three new species of the genus Philora are described: Philora izel sp. nov., Philora mazateca sp. nov. and Philora nympha sp. nov. Two of these, $P$. izel and $P$. nympha exhibit remarkable troglomorphisms (adaptations to life in caves), such as depigmentation, absence of eyes and elongation of appendages. These conditions are discussed and their ocurrence is compared with the other 3 species of the genus that do not exhibit troglomorphisms. A dichotomic key to identify the 5 known species of the genus is provided.

All Rights Reserved (C) 2016 Universidad Nacional Autónoma de México, Instituto de Biología. This is an open access item distributed under the Creative Commons CC License BY-NC-ND 4.0.
\end{abstract}

Keywords: Laniatores; Diversity; Taxonomy; Troglomorphisms

\section{Resumen}

Se describen 3 especies nuevas del género Philora: Philora izel sp. nov., Philora mazateca sp. nov. y Philora nympha sp. nov. Dos de estas especies, $P$. izel y $P$. nympha exhiben notables troglomorfismos (adaptaciones para la vida en cuevas), tales como decoloración, ausencia de ojos y elongación de los apéndices. Se discuten estas condiciones y su presencia y se comparan con las 3 especies del género restantes, las cuales no presentan estas características. Se provee una clave para la identificación de las 5 especies del género.

Derechos Reservados ( 2016 Universidad Nacional Autónoma de México, Instituto de Biología. Este es un artículo de acceso abierto distribuido bajo los términos de la Licencia Creative Commons CC BY-NC-ND 4.0.

Palabras clave: Laniatores; Diversidad; Taxonomía; Troglomorfismos

\section{Introduction}

The North American harvestman genus Philora Goodnight and Goodnight, 1954 is comprised of 2 remarkable species with scutum completum and low tarsal count 2(1):2(1):4:4 (Cruz-López \& Francke, 2013b), characters that are unusual within suborder Laniatores (Sharma \& Giribet, 2011). These

\footnotetext{
* Corresponding author.

E-mail address: thelyphonidito@gmail.com (J.A. Cruz-López).

Peer Review under the responsibility of Universidad Nacional Autónoma de México.
}

characters are also present in Sandokanidae, Heteropachylus inexpectabilis (Soares \& Soares, 1946) and presumably in Paralola buresi Kratochvíl, 1951 (Mendes, 2011; Sharma \& Giribet, 2009; Ubick, 2007). The genus Philora was recently revised, rediagnosed and transferred from incertae sedis within Laniatores to the familial assignment in Stygnopsidae (CruzLópez \& Francke, 2013b). Cruz-López and Francke (2013b) also discussed the morphological similarities in male genitalia present in Paramitraceras Pickard-Cambridge, 1905, Philora, and Troglostygnopsis anophthalma Šilhavý, 1974, describing the Paramitraceras-pattern among Stygnopsidae (Cruz-López \& Francke, 2013b). Subsequently, Kury and Villarreal (2015) 
Table 1

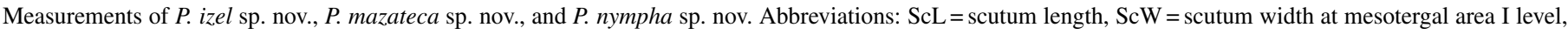
$\mathrm{ChH}=$ cheliceral hand height.

\begin{tabular}{|c|c|c|c|c|c|c|c|}
\hline & & Trochanter & Femur & Patella & Tibia & Metatarsus & Tarsus \\
\hline P. izel & Pedipalp & 0.23 & 1.00 & 0.40 & 0.76 & - & 0.66 \\
\hline ScL 2.66 & LI & 0.21 & 0.96 & 0.33 & 0.66 & 0.71 & 0.50 \\
\hline ScW 1.73 & LII & 0.26 & 1.23 & 0.48 & 0.96 & 1.00 & 0.93 \\
\hline \multirow[t]{2}{*}{ ChH 0.98} & LIII & 0.30 & 1.10 & 0.38 & 0.83 & 0.88 & 0.53 \\
\hline & LIV & 0.36 & 1.40 & 0.53 & 1.10 & 1.30 & 0.60 \\
\hline P. mazateca & Pedipalp & 0.26 & 0.70 & 0.33 & 0.46 & - & 0.43 \\
\hline ScL 2.33 & LI & 0.21 & 0.86 & 0.33 & 0.60 & 0.63 & 0.48 \\
\hline ScW 1.50 & LII & 0.26 & 1.06 & 0.45 & 0.81 & 0.86 & 0.71 \\
\hline \multirow[t]{2}{*}{ ChH 0.71} & LIII & 0.23 & 0.96 & 0.33 & 0.73 & 0.73 & 0.46 \\
\hline & LV & 0.30 & 1.23 & 0.43 & 1.00 & 1.20 & 0.46 \\
\hline P. nympha & Pedipalp & 0.23 & 0.86 & 0.40 & 0.60 & - & 0.66 \\
\hline ScL 2.60 & LI & 0.26 & 2.00 & 0.63 & 1.40 & 1.80 & 1.23 \\
\hline ScW 1.53 & LII & 0.70 & 3.40 & 0.96 & 2.53 & 2.73 & 2.93 \\
\hline \multirow[t]{2}{*}{ ChH 0.96} & LIII & 0.40 & 2.70 & 0.63 & 1.76 & 2.56 & 1.13 \\
\hline & LIV & 0.43 & 3.50 & 0.83 & 2.53 & 3.95 & 1.26 \\
\hline
\end{tabular}

proposed the first penial setae homology assessment among Gonyleptoidea (Kury \& Villarreal, 2015). In that work, the authors described 5 groups of setae based on topological criteria; with respect to Stygnopsidae, these groups were recognized in Hoplobunus boneti (Goodnight \& Goodnight, 1942), Karos sp. and the genera with the Paramitraceras-pattern (Kury \& Villarreal, 2015). Recently, Cruz-López and Francke (2015) based on a cladistics analysis, recognized that all members with the Paramitraceras-pattern form a clade, supported by synapomorphies related to characters from the penis, and formally recognized the Paramitraceras genus-group (Cruz-López \& Francke, 2015).

Recent collecting trips to the states of Oaxaca and Puebla, Mexico, produced some specimens of 2 epigean and 1 cavernicolous new species of Philora, described in the present work. One of the epigean species and the cavernicolous species show remarkable troglomorphisms, i.e. morphological adaptations associated with life underground, illustrated and discussed below. Additionally, a taxonomic key is provided to identify the 5 known species of Philora.

\section{Materials and methods}

The material examined is deposited in the Colección Nacional de Arácnidos (CNAN), UNAM, Mexico. Color images were taken with a Nikon Coolpix S10 VR camera adapted to fit in a Nikon SMZ645 stereoscopic microscope. Drawings were made in Photoshop CS5 software, using assembled photographs to delineate the structures. All plates were edited using the previously mentioned version of Photoshop. Measurements are in $\mathrm{mm}$. External morphology nomenclature was modified from Cruz-López and Francke (2013b) and Kury (2014). Abbreviations: $\mathrm{ChH}=$ cheliceral hand height, $\mathrm{ScL}=$ scutum length, $\mathrm{ScW}=$ scutum width at mesotergal area I. Genitalic nomenclature according to Kury and Villarreal (2015). The distribution map was generated using the Mapa Digital de México to desktop software, ver. 6.0.1, using geographic information from WMS service on-line (http://gaia,inegi.org.mx/NLB/mdm5.wms).

\section{Descriptions}

\section{Preliminary considerations, genital nomenclature modifications}

Cruz-López and Francke (2013b) described the Paramitraceras-pattern, present in at least Paramitraceras, Philora and Troglostygnopsis (Šilhavý, 1974). These authors recognized the position pattern in all macrosetae in pars distalis, named 3 setal groups: dorso-lateral or mesal, laterobasal and ventral microsetae.

Kury and Villarreal (2015) proposed the first hypothesis of homology in macrosetae in Gonyleptoidea. They described 5 setal groups according to topological criteria. Kury \& Villarreal identified these groups in Hoplobunus boneti, Karos sp. and the genera with Paramitraceras pattern. According to Kury and Villarreal (2015), setal group C is: "short, grouped subapically (as in the Paramitraceras-Troglostygnopsis complex)", "no common pattern for family is discernible other than the number of 2 pairs C1-C2 and the subdistal insertion." We adopt herein the hypothesis and nomenclature of Kury \& Villarreal, but we consider that setal group $\mathrm{C}$ is not recognizable at least in Philora. Group C is easily recognizable in Paramitraceras as a transversal row along the lateral margin of pars distalis, sometimes almost touching E2 setae (Cruz-López \& Francke, 2012: figs. 13-15; Cruz-López \& Francke, 2013a: figs. 25-27, 37-39); in Troglostygnopsis these setae are found as a small transversal row of 3 spiniform setae, differing from spatular macrosetae in the A + B groups (Cruz-López \& Francke, 2013b: figs. 49, 52). Therefore, in Philora the lateral macrosetae of penis are herein considered as a complex formed by the A + B groups, the 2 ventral pairs conform the E group, and 1 pair of a small D1 setae are present. Cruz-López and Francke (2013b) showed the small D1 setae in P. quetzalzin (Cruz-López \& Francke, 2013b: figs. 28, 31 ), but they did not describe or mentioned these setae. For the present contribution, a cursory examination of male genitalia of P. tuxtlae exposed the presence of D1 setae, with the same size and position as the other species of the genus described herein. 
Identification key to the species of Philora.

1. Color pale cream; legs noticeably elongated, femur IV $>3.4 \mathrm{~mm}$, tarsus II $>2.90 \mathrm{~mm}$ (Fig. 13; Table 1)

Philora nympha sp. nov.

$1^{\prime}$. Colored dark brown or orange; legs not elongated, femur IV $<1.5 \mathrm{~mm}$, tarsus II $<1.00 \mathrm{~mm}$ (Figs. 1, 7; Table 1) .....

Philora izel sp. nov.

2. Body and legs light orange in color; ocelli reduced in size and unpigmented, almost absent (Fig. 1)

$2^{\prime}$. Body brown in color, with median portion of mesotergal areas almost black; ocelli not reduced in size and well pigmented (Fig. 7)

Dorsum covered by small rounded setiferous tubercles (Cruz-López \& Francke, 2013b: figs. 17-19)

4. Dorsoapical spiniform setiferous tubercle on metatarsus IV distinctly apical (Cruz-López \& Francke, 2013b: fig. 7); with 2 sets of macrosetae A + B, 1 meso-apical with 3 setae, the other at the base of glans, with 3 setae (Cruz-López \& Francke, 2013b: figs. 12, 13)

$4^{\prime}$. Dorsoapical spiniform setiferous tubercle on metatarsus IV distinctly sub-distal (Fig. 4F); with 2 sets of macrosetae A + B, the meso-apical with 4 setae, the other at the base of glans, with 4 setae (Fig. 12)

Philora mazateca sp. nov.

Philora izel sp. nov. (Figs. 1-6)

\section{Diagnosis}

This species differs from all others by the presence of the following characters: light orange color (Fig. 1), uniform throughout body and appendages; eyes very reduced and unpigmented; ocularium strong, with the base very wide, anterior face swollen; surface of prosoma posterior to ocularium raised, forming a dome (Fig. 2D).

Description of male holotype. Dorsum: base of ocularium very wide, anterior face swollen, apex forming a small tip, pointing anteriorly. Surface of prosoma posterior to ocularium elevated, forming a dome (Fig. 2D). Eyes very reduced and unpigmented. Prosoma smooth, ocularium covered with


Figure 1. Philora izel sp. nov. A, B, male holotype habitus, dorsal and lateral views. few, small, scattered tubercles; mesotergal areas finely granular, with few, small scattered tubercles, stand out on area I (Figs. 2, 5A). Venter: all surface covered by tubercles, on coxae I and II with long spiniform setiferous tubercles; 4 setiferous tubercles on stigmatic area, blunt and contiguous, just behind coxa IV (Fig. 5B). Chelicera: basichelicerite short, bulla well marked with distinct constriction, with 2 acute spiniform teeth,

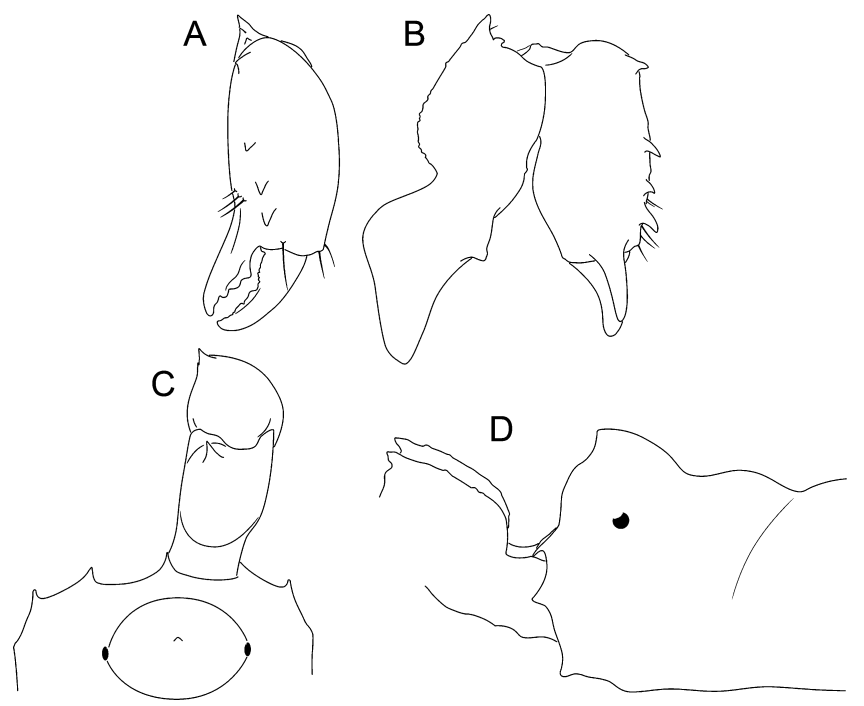

Figure 2. Philora izel sp. nov. Male holotype: A, B, chelicera, frontal and mesal views. C, D, carapace, dorsal and lateral views.

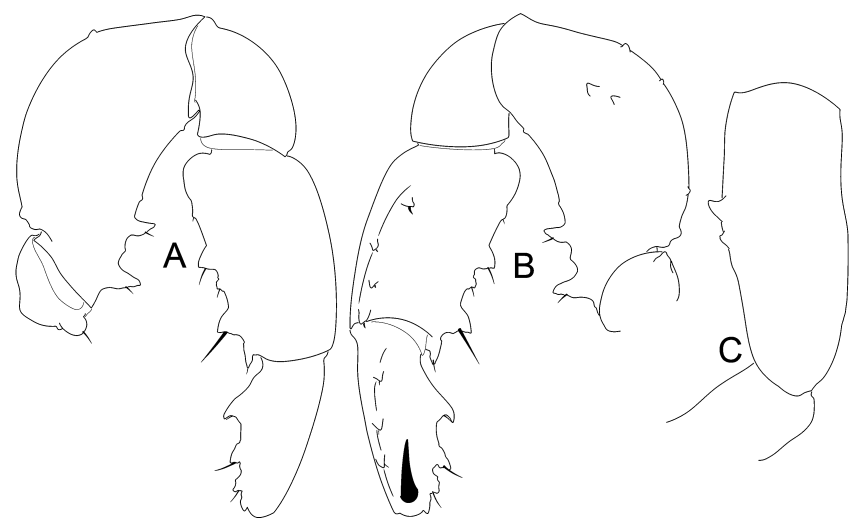

Figure 3. Philora izel sp. nov. Male holotype: A, B, pedipalp, ectal and mesal views. C, pedipalp femur, dorsal view. 

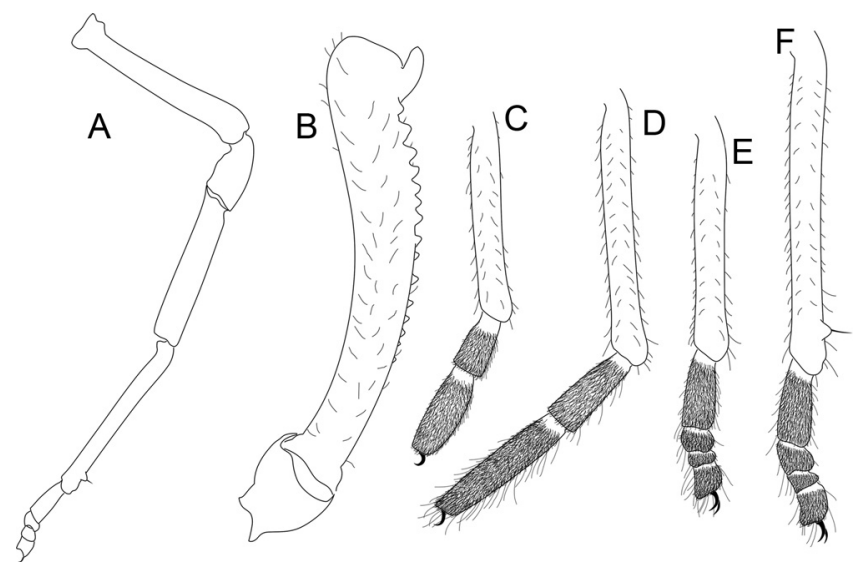

Figure 4. Philora izel sp. nov. Male holotype, legs: A, leg IV ectal view. B, femur IV prolateral view. C-F, metatarsus and tarsus, lateral views, legs I-IV.

1 dorso-apical and 1 ventral, just behind notch of bulla; cheliceral hand slightly swollen medially, with 4 spiniform tubercles and few spiniform setae on frontal side; cheliceral fingers: fixed finger with 3 blunt teeth, decreasing in size toward the apical portion, movable finger with basal serrula and 2 small teeth in the middle (Fig. 2A, B). Pedipalp: femur hardly convex dorsally, mesal face feebly concave, ventral face reduced, basally with 2 large setiferous tubercles, these tubercles with strong spiniform sockets, and small sub-apical seta; patella cylindrical, without noticeable ornamentation; tibia quadrangular in cross-section, internal face slightly concave, with rounded projection at the base of ectal border, both edges with 4 setiferous tubercles, similar to those ventrally on femur; tarsus tapering distally, with 3 setiferous tubercles each on ectal and mesal edges (Fig. 3). Male genitalia: lateral margins of pars distalis rolled dorsally, apical margin with 2 paramedian lobes pointed dorsally. 9 pairs of macrosetae $\mathrm{A}+\mathrm{B}$ forming 2 irregular row across the lateral margin of pars distalis, latero-basally to glans. D1 setae not
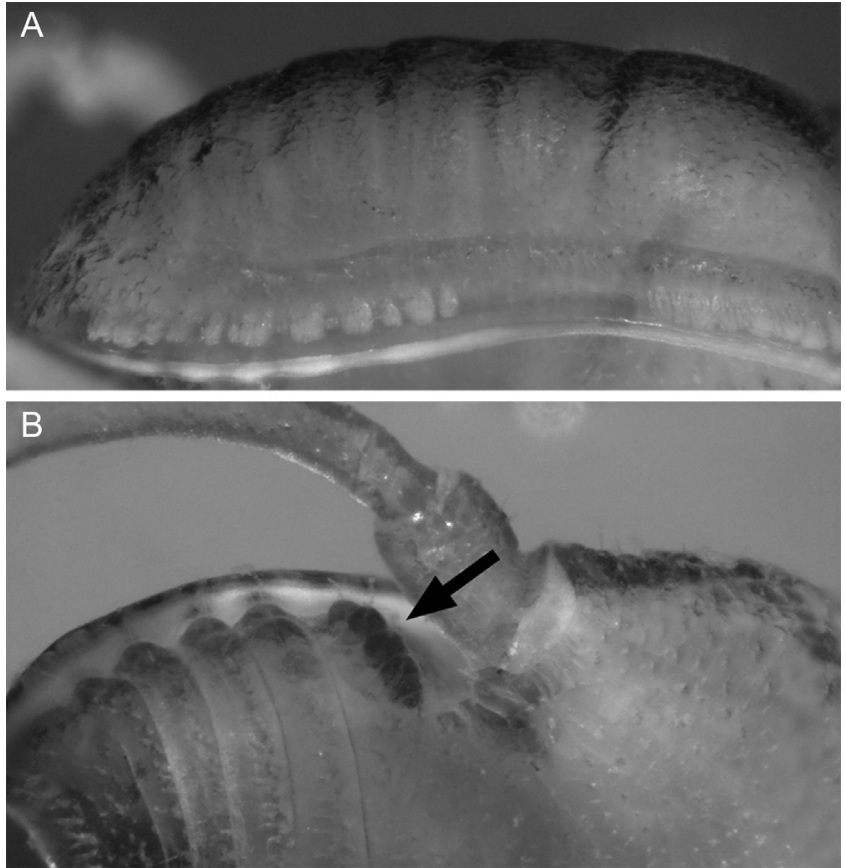

Figure 5. Philora izel sp. nov. Male holotype. A, dorsal ornamentation. B, setiferous tubercles on stigmatic area.

visible. Setae E ventral subapically, E1 slightly above of E2. Lobes of dorsal bilobular proyection with dotted apices (Fig. 6).

Female. Unknown.

Distribution. Known only from the type locality (Fig. 19).

\section{Taxonomic summary}

Type data: male holotype (CNAN-T0939) from Cerro Caballero ( $\left.18^{\circ} 08^{\prime} 32.28^{\prime \prime} \mathrm{N}, 96^{\circ} 42^{\prime} 57.491^{\prime \prime} \mathrm{W}\right)$, municipio de San José Tenango, Oaxaca, Mexico. April 10-2014 (O. Francke, J. Cruz, G. Contreras, J. Mendoza, A. Guzmán and S. Davlañtes coll.).
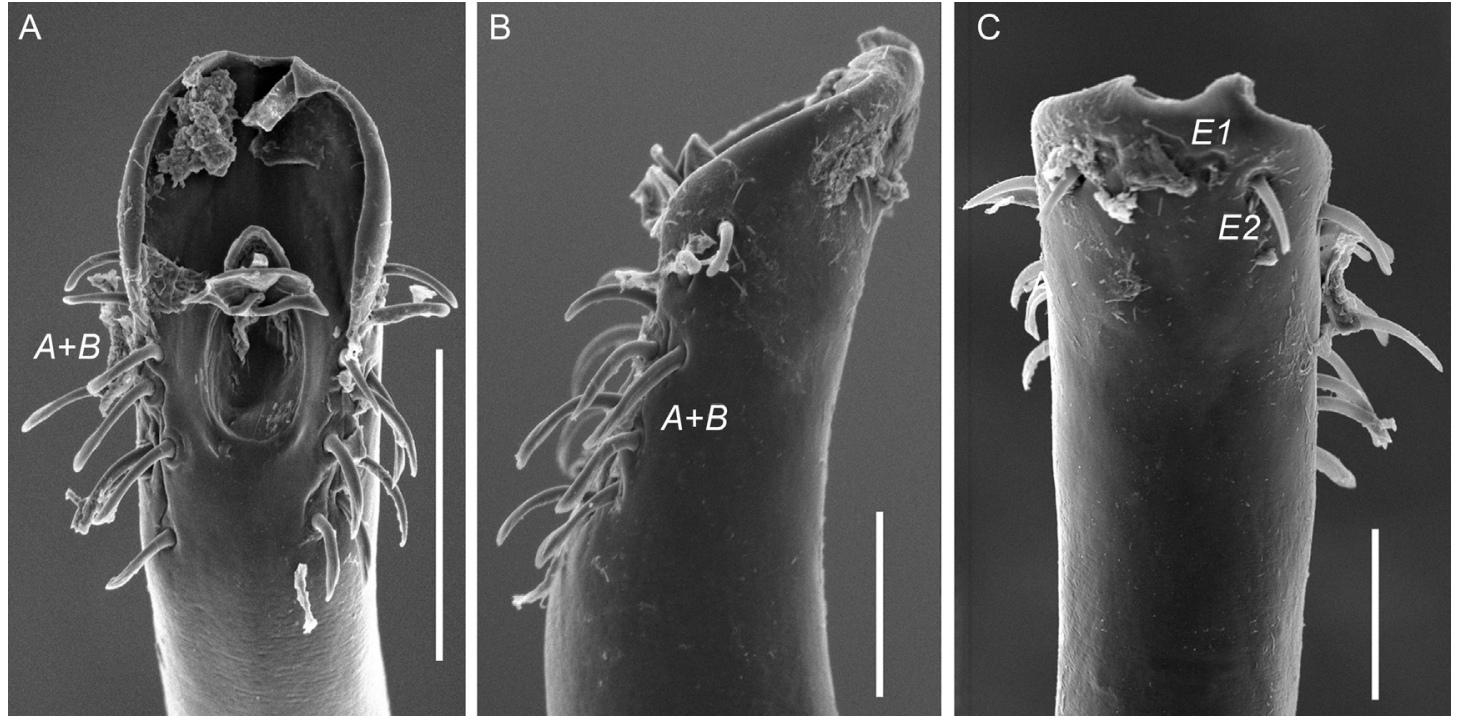

Figure 6. Philora izel sp. nov. Male genitalia, A, frontal view. B, lateral view. C, ventral view. Scale bars A=100 $\mu \mathrm{m}, \mathrm{B}$ and C $=50 \mu \mathrm{m}$. Setae groups A $+\mathrm{B}$ and E indicated. 

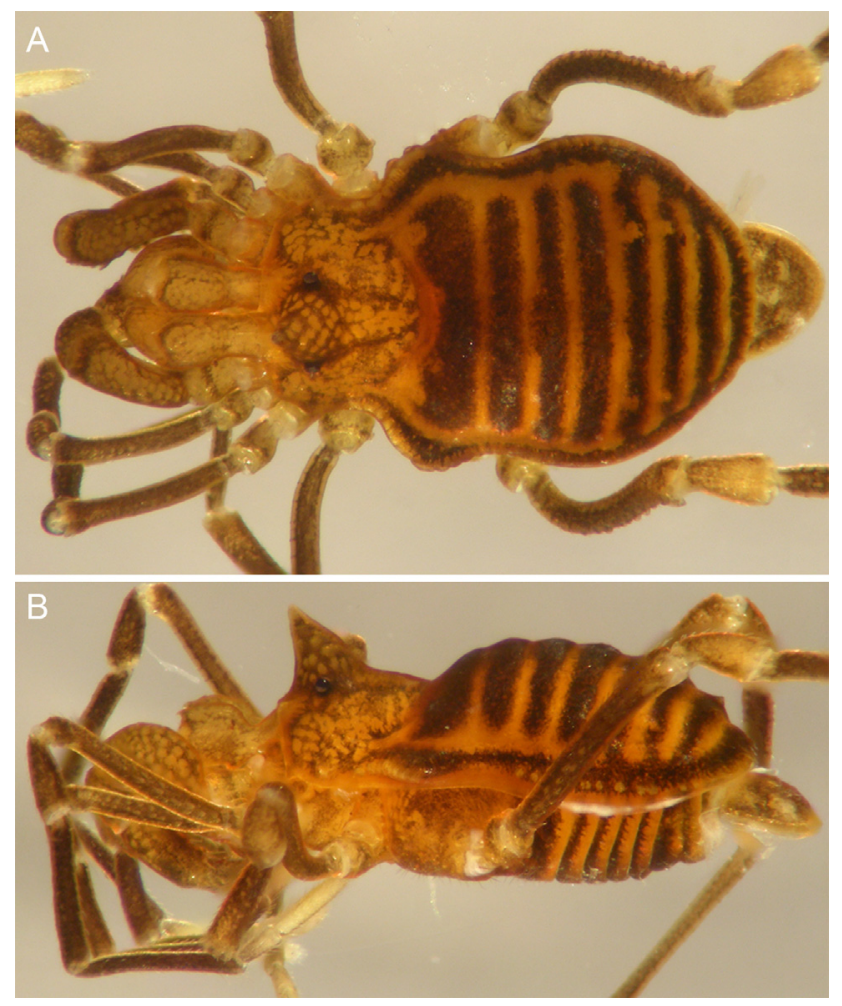

Figure 7. Philora mazateca sp. nov. A, B, male holotype habitus, dorsal and lateral views.

Etymology. Specific name feminine adjetive, from the Nahuatl word "izel", meaning unique, remarkable; alluding to the unusual troglomorphisms exhibited by this presumably epigean species.

Philora mazateca sp. nov. (Figs. 7-12)

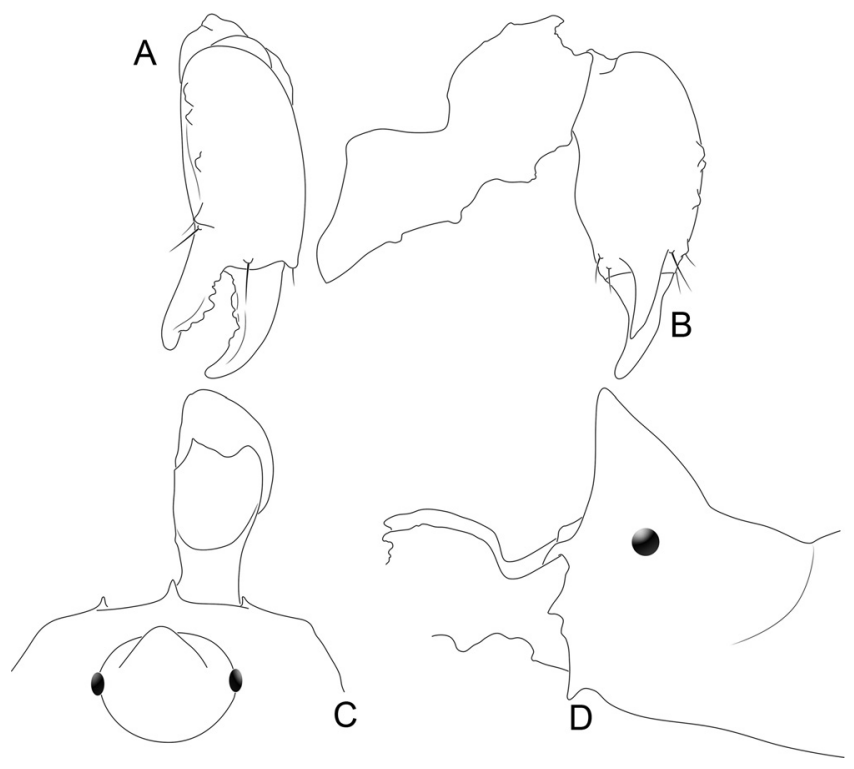

Figure 8. Philora mazateca sp. nov. Male holotype: A, B, chelicera, frontal and mesal view. C, D, carapace, dorsal and lateral views.

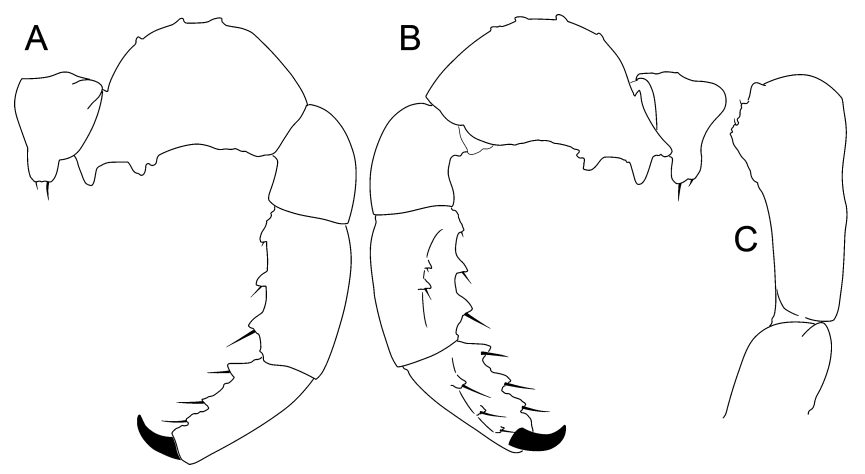

Figure 9. Philora mazateca sp. nov. Male holotype: A, B pedipalp, ectal and mesal views. C, pedipalp femur, dorsal view.

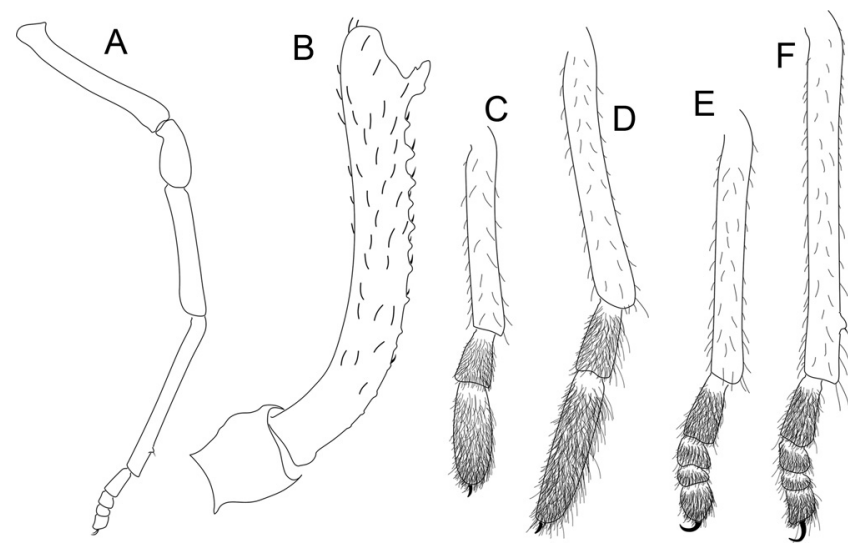

Figure 10. Philora mazateca sp. nov. Male holotype, legs: A, leg IV ectal view. $\mathrm{B}$, femur IV prolateral view. C-F, metatarsus and tarsus, lateral views, legs I-IV.
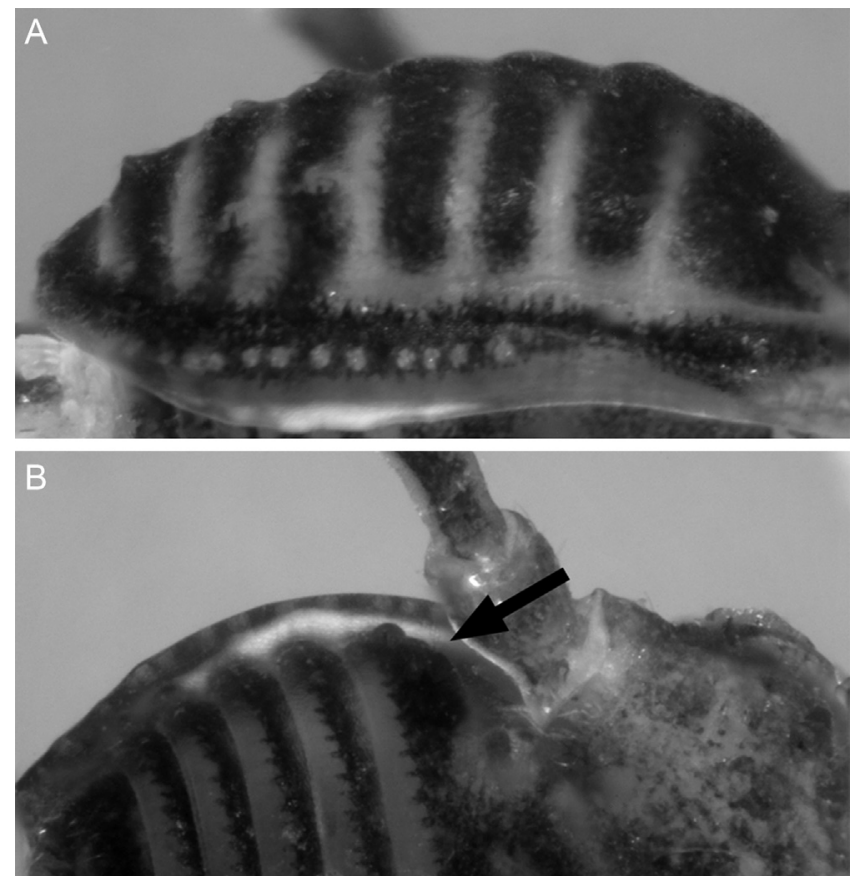

Figure 11. Philora mazateca sp. nov. Male holotype. A, dorsal ornamentation. $\mathrm{B}$, setiferous tubercles on stigmatic area. 


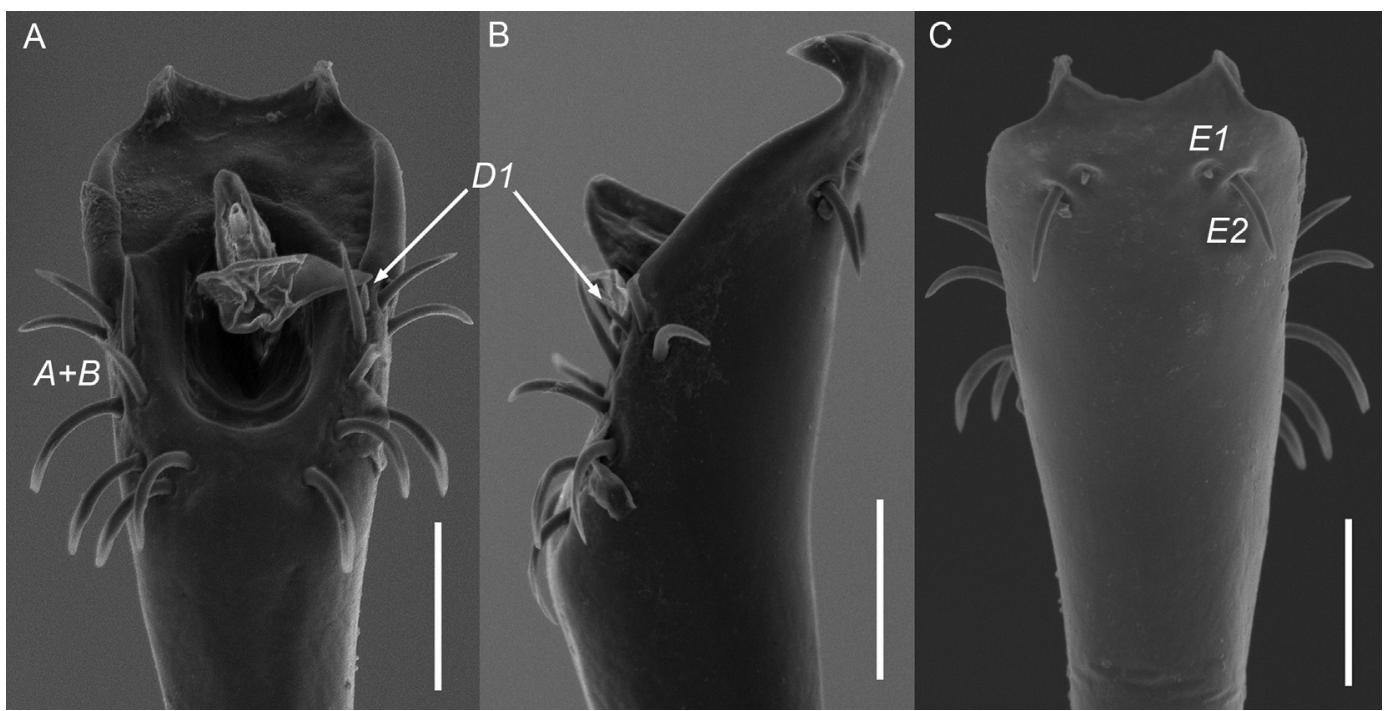

Figure 12. Philora mazateca sp. nov. Male genitalia: A, frontal view. B, lateral view. C, ventral view. Scale bars $=50 \mu \mathrm{m}$. Setae groups A+B, E and D indicated.

\section{Diagnosis}

This species is easily recognizable from $P$. izel sp. nov. and $P$. nympha sp. nov. by the mostly bicolored body, light brown background with the reticular pattern around the margin of the scutum, central portion of mesotergal areas and on prosoma, and the ocularium very dark, almost black (Fig. 7). This species differs from $P$. quetzalzin in that the base of ocularium is not widened on $P$. mazateca, the surface of prosoma posterior to ocularium is not raised, and the dorsum is finely granular, with few scattered blunt tubercles on areas V-VII (Fig. 11A). It differs from $P$. tuxtlae in following characters: dorso-apical tubercle on metatarsus IV sub-distally rather than apically (Fig. 10F), movable cheliceral finger with small teeth rather than almost smooth (Fig. 8A) and number of macrosetae on penis.

Description of male holotype. Dorsum: ocularium conical, base elliptical, apex forming a blunt tip pointing forward; surface of prosoma posterior to ocularium not elevated. Eyes well pigmented and marked (Fig. 8). Prosoma and ocularium smooth, mesotergal areas finely granular, with blunt scattered tubercles in central portion of areas V-VIII (Fig. 11A). Venter: covered by small scattered tubercles, coxae I and II with small setiferous tubercles; 3 setiferous tubercles on stigmatic area, blunt and contiguous, just behind coxa IV (Fig. 11B). Chelicera: basichelicerite short, bulla well marked, with distinct constriction, with 2 spiniform teeth, the dorso-apical irregular and the ventral 1 slightly distal from the notch of bulla, blunt; cheliceral hand with 4 frontal setiferous tubercles, the apical bigger, also covered by some spiniform setae; fixed finger with 3 middle teeth, blunt and contiguous, basally with small teeth and inconspicuous notches; movable finger with 2 small and contiguous median teeth, and 1 median notch, slightly distal to the teeth (Fig. 8A, B). Pedipalp: femur convex dorsally, mesal face concave, ventral area reduced, with 3 large spiniform setiferous tubercles, the 2 apical tubercles contiguous at their bases; patella cylindrical, unarmed; tibia sub-quadrangular in cross-section, with the internal face concave, ectal edge with 3 setiferous tubercles, mesal with 2, in both edges similar to those ventrally on femur; tarsus tapering distally, with 3 setiferous tubercles on each edge (Fig. 9). Male genitalia: paramedian lobes of apical margin long and rounded, pointed dorsally. Apical margin concave. 7-8 setae A + B forming an irregular group, 3-4 of them surrounding small D1 setae, the remaining in the base of pars distalis. Setae E subapically, both pairs noticeably separated between them, E1 slightly above of E2. Lobes of dorsal bilobular proyection wide, with dotted apices (Fig. 12).

Female paratype. Very similar to male, recognizable only by the absence of 4 ventral light-colored pointed areas (Cruz-López \& Francke, 2013b).

Distribution. Known only from the type locality and 1 nearby locality (Fig. 19).

\section{Taxonomic summary}

Type data: male holotype (CNAN-T0940) $600 \mathrm{~m}$ from Pozo de Águila $\left(18^{\circ} 11^{\prime} 51.792^{\prime \prime} \mathrm{N}, 96^{\circ} 40^{\prime} 36.552^{\prime \prime} \mathrm{W}\right)$, Municipio de San José Tenango, Oaxaca, Mexico. April 11-2014 (O. Francke, J. Cruz, G. Contreras, J. Mendoza, A. Guzmán and S. Davlañtes coll.). 3 female and 1 juvenile paratypes (CNAN-T0941) same data as holotype.

Other material examined: female DNA voucher (DNA-Op0046) from Cerro Caballero $\left(18^{\circ} 08^{\prime} 8.88^{\prime \prime} \mathrm{N}\right.$, $\left.96^{\circ} 41^{\prime} 22.92^{\prime \prime} \mathrm{W}\right)$, Municipio de San José Tenango, Oaxaca, Mexico. September 30-2008 (J. Cruz coll.).

Etymology. The specific name is feminine, a noun used in apposition, derived from the Spanish word "mazateca", a demonym which refers to the Mexican ethnic group that lives in the region of the type locality.

Philora nympha sp. nov. (Figs. 13-18)

\section{Diagnosis}

This species is easily recognizable from all the other members of the genus by the following characters: general pale white 

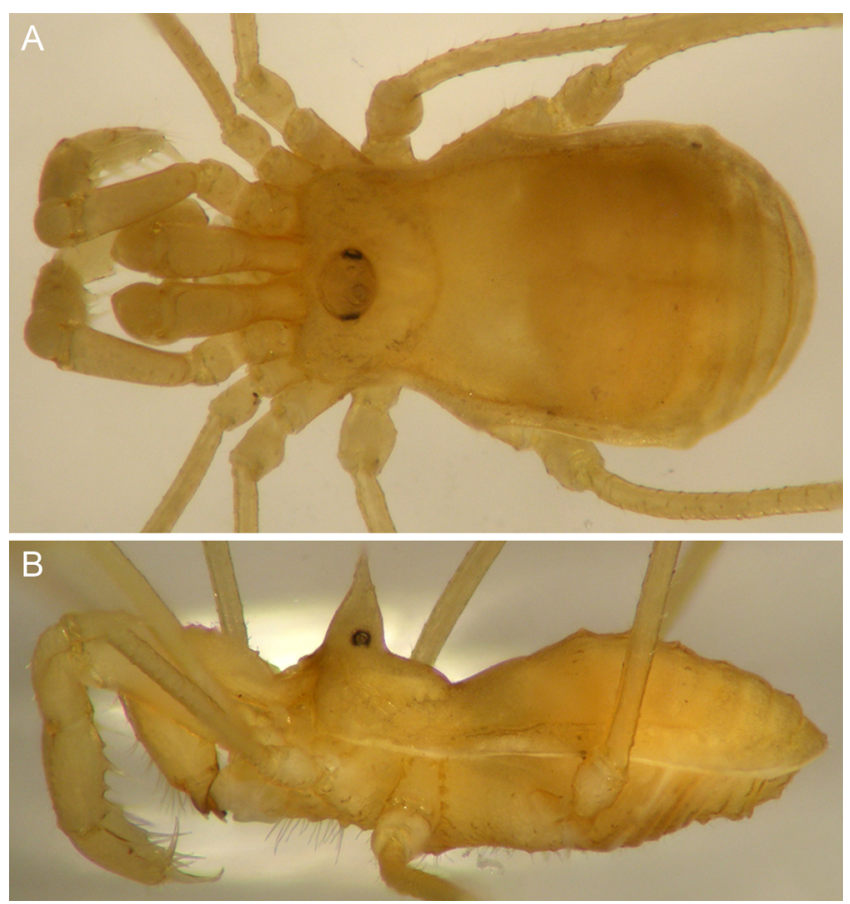

Figure 13. Philora nympha sp. nov. A, B, male holotype habitus, dorsal and lateral views.

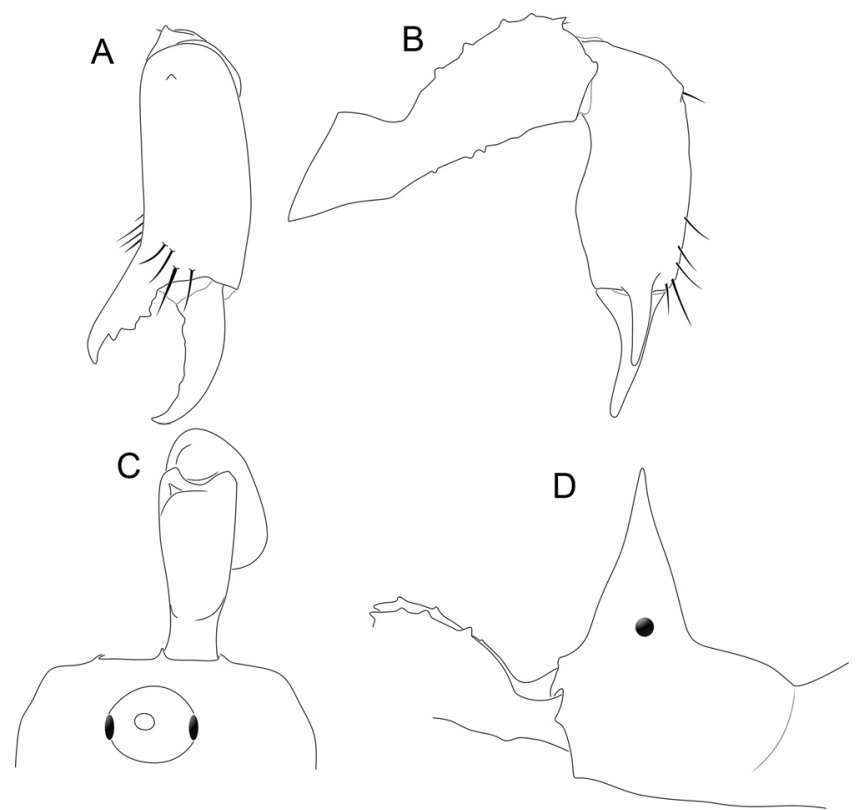

Figure 14. Philora nympha sp. nov. Male holotype: A, B, chelicera, frontal and mesal views. C, D, carapace, dorsal and lateral views.

color throughout body and appendages (Fig. 13); basichelicerite, pedipalp, pedipalpal armature and legs very long (Figs. 14-16), femur IV $>3.4 \mathrm{~mm}$, tarsus II $>2.90 \mathrm{~mm}$.

Description of male holotype. Dorsum: ocularium conical, elongated and finely acute in the apex, pointing dorsally; surface of prosoma posterior to ocularium slightly elevated; eyes well marked and pigmented; prosoma and ocularium smooth, mesotergal areas finely granular, with a central row of small setiferous tubercles on areas II-VII (Figs. 14C, D, 17A). Venter:

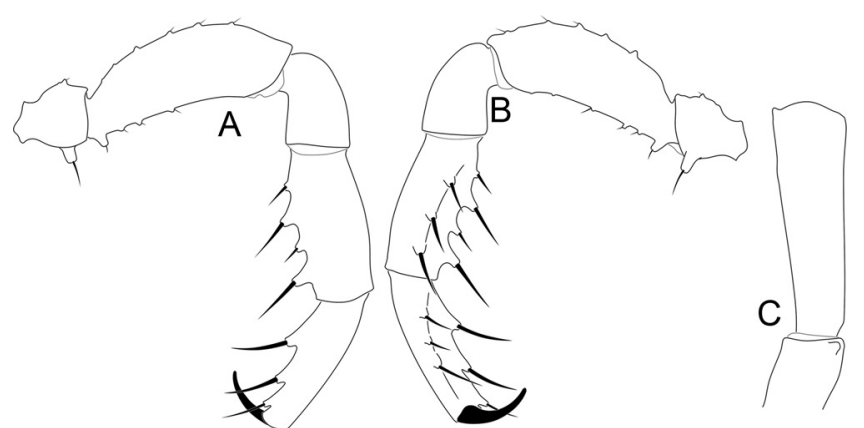

Figure 15. Philora nympha sp. nov. Male holotype: A, B, pedipalp, ectal and mesal views. C, pedipalp femur, dorsal view.

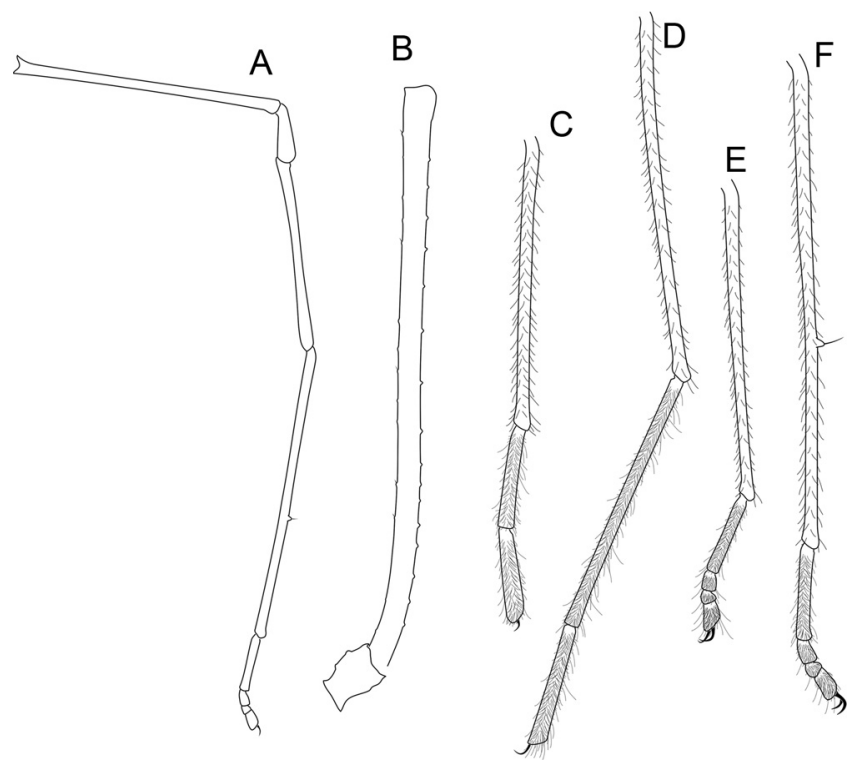

Figure 16. Philora nympha sp. nov. Male holotype, legs: A, leg IV ectal view. $\mathrm{B}$, femur IV prolateral view. C-F, metatarsus and tarsus, lateral views, legs I-IV.
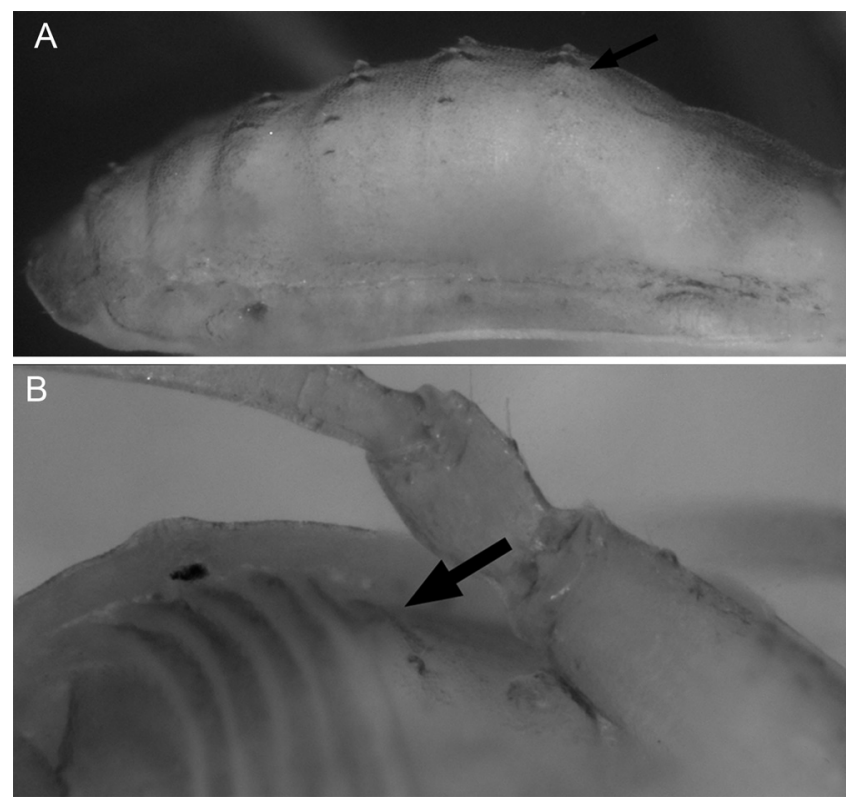

Figure 17. Philora nympha sp. nov. Male holotype. A, dorsal ornamentation. B, setiferous tubercles on stigmatic area. 


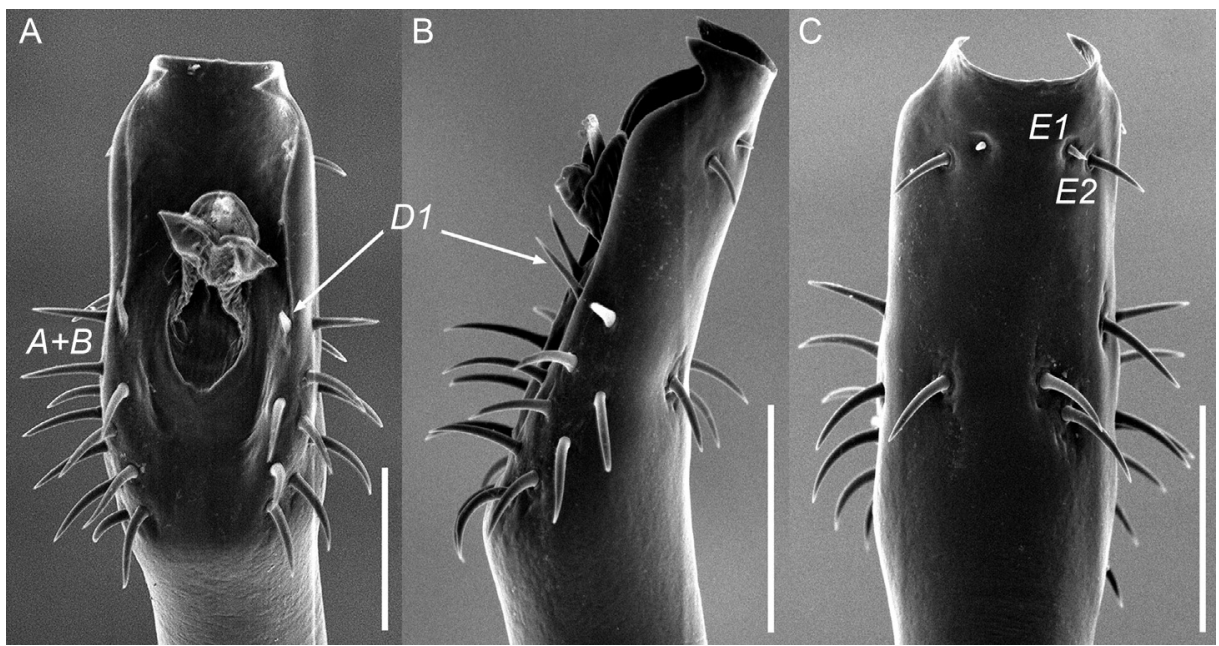

Figure 18. Philora nympha sp. nov. Male genitalia: A, frontal view. B, lateral view. C, ventral view. Scale bars $=100 \mu \mathrm{m}$. Setae groups A $+\mathrm{B}, \mathrm{E}$ and $\mathrm{D}$ indicated.

covered by small scattered tubercles; coxae I and II with long, spiniform setiferous tubercles, these tubercles with the apical setae very long; with 3 setiferous tubercles behind coxa IV, 2 of them very wide and fused, giving blunt dome appearance (Fig. 17B). Chelicera: basichelicerite elongated, bulla subtly marked with shallow constriction, extending more than 3 fourths of the basichelicerite length, dorsoapical spiniform tooth small, ventral absent; cheliceral hand covered only with spiniform setae, near the cheliceral fingers; fixed finger with 4 middle teeth, contiguous, central pair more developed; movable finger with small basal tooth, and serrula covering almost entire length (Fig. 14A, B). Pedipalp: femur quadrangular in crosssection, ventrally with 4 small setiferous tubercles, scattered along the entire length; patella without remarkable ornamentation; tibia quadrangular in cross-section, mesal edge with 3 spiniform setiferous tubercles, ectal with 4; tarsus tapering distally, with 4 setiferous tubercles on each edge; all setae of pedipalpal armature inserted apically on the tubercle, rather than subdistally (Fig. 15). Male genitalia: paramedian lobes acute apically, pointed dorso-internally. With 11-12 A + B setae, forming 2 longitudinal rows, the dorsal row along the lateral margin, the ventral row from the base of pars distalis to ventral position, below to E setae. D1 setae long, in the inner side of lateral margin. E1 setae slightly apical to E2. Lobes of dorsal bilobular projection triangular shape, with dotted apices (Fig. 18).

Female paratype. Very similar to male, barely distinguishable by the absence of 4 ventral light-colored pointed areas (CruzLópez \& Francke, 2013b).

Distribution. Known only from the type locality (Fig. 19).

\section{Taxonomic summary}

Type data: male holotype (CNAN-T0942) from Chupa Cave $\left(18^{\circ} 18^{\prime} 55.728^{\prime \prime} \mathrm{N}, 96^{\circ} 52^{\prime} 4.908^{\prime \prime} \mathrm{W}\right)$, Municipio de Tequixtepec, Puebla, Mexico. March 12-2014 (L. Bouchard, M. Archambault coll.). 2 female paratypes (CNAN-T0943) with same data as holotype.

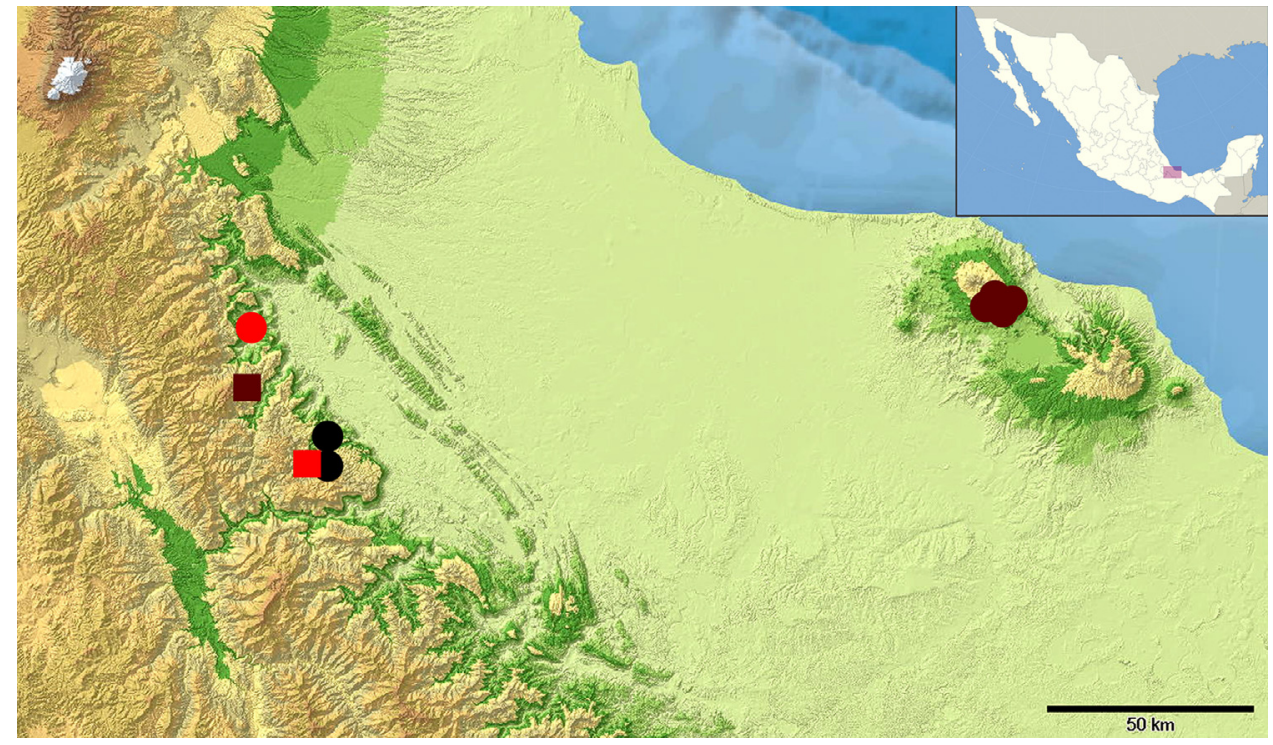

Figure 19. Distribution map of the species of Philora. Philora tuxtlae purple circles, P. quetzalzin red circle, P. izel sp. n. red square, P. mazateca sp. n. black circles, and $P$. nympha sp. n. purple square. 
Etymology. Specific name is feminine, a noun in apposition derived from the Greek word " $\nu v \mu \varphi \alpha$ " (nymph), in reference to minor divinities in Greco-Roman culture and often represented as beautiful maidens. It was believed that they sometimes lived inside caves.

\section{Discussion}

The epigean species $P$. quetzalzin, $P$. mazateca and $P$. tuxtlae have the cryptic coloration of the body, with background color brown with darks areas. This color pattern plus thanatotic behavior suggest specific habits to life in leaf litter, which is where these species have been retrieved from (Cruz-López \& Francke, 2013b). On the other hand, P. izel exhibits light orange color, uniform in all body and appendages, and reduced and unpigmented eyes, characters usually correlated with cavernicolous habits (Christiansen, 2012), even though the single known specimen was collected on the surface under a large rock and not inside a cave. However, it is known that some epigean species of harvestmen exhibit light color body, eye reduced or lost, and occasionally legs elongation (González-Sponga, 1997; Kauri, 1989; Pérez-González \& Kury, 2007; Pinto-da-Rocha \& Kury, 2003). These characters have been associated to the specific ecological niche of these species, which might have similar light and humidity conditions to those found in caves, although this hypothesis has not been tested.

Even though P. izel and P. mazateca are from the same type locality, the specimens of $P$. mazateca were collected by sifting leaf litter, a technique previosly used to collect epigean P. tuxtlae (Cruz-López \& Francke, 2013b). The holotype of P. izel was found by chance inside a small pit in a deeply buried rock, similar micro-habitat to that of the ricinuleid Pseudocellus cruzlopezi Valdez-Mondragón \& Francke, 2013 (Valdez-Mondragón \& Francke, 2013). Further studies are needed to determine if the "troglomorphisms" in P. izel are due to environmental conditions of its particular ecological niche, or perhaps the male wandered outside a hidden cave through a small crevice in search of mates.

The cavernicolous $P$. nympha exhibits typical troglomorphic characters: pale color and remarkably long legs, and incredibly delineated and pigmented eyes. The type specimens were found walking in the walls of cave (collectors label) so that, the long legs could represent an adaptative change from inhabiting leaf litter to a wandering habit inside the cave.

\section{Acknowledgements}

The first author thanks Conacyt, Posgrado en Ciencias Biológicas and Instituto de Biología, UNAM for financial support. We thank the members of Proyecto Espeleológico Sistema Huautla, especially to S. Davlañtes for support during field work in the Huautla region. Thanks to members of the CNAN, for their effort in the field, especially G. Contreras, R. Monjaraz and J. Mendoza, for their unconditional support in physically demanding speleological trips each year. We thank
B. Mendoza-Garfias for her assistance with SEM images. We thank A.B. Kury and an anonymous reviewer for their comments and suggestions to improve the manuscript. Specimens were collected under scientific permit FAUT-175 from Semarnat to O.F. Francke.

\section{References}

Christiansen, K. (2012). Morphological adaptation. In W. B. White, \& D. C. Culver (Eds.), Encyclopedia of Caves (2nd ed., pp. 517-528). New York: Elsevier Inc.

Cruz-López, J. A., \& Francke, O. F. (2012). Una especie nueva del género Paramitraceras Pickard-Cambridge (Opiliones: Laniatores: Stygnopsidae) de Veracruz, México. Revista Ibérica de Aracnología, 20, 17-23.

Cruz-López, J. A., \& Francke, O. F. (2013a). Two new species of the genus Paramitraceras Pickard-Cambridge, 1905 (Opiliones: Laniatores: Stygnopsidae) from Chiapas, Mexico. Zootaxa, 3641, 48-490.

Cruz-López, J. A., \& Francke, O. F. (2013b). On the enigmatic genus Philora familial assignment and taxonomic revision (Opiliones: Laniatores: Stygnopsidae). Journal of Arachnology, 41, 291-305.

Cruz-López, J. A., \& Francke, O. F. (2015). Cladistic analysis and taxonomic revision of the genus Karos Goodnight \& Goodnight, 1944 (Opiliones, Laniatores, Stygnopsidae). Zoological Journal of the Linnean Society, 175, 827-891.

González-Sponga, M. A. (1997). Arácnidos de Venezuela. Una nueva familia, dos nuevos géneros y dos nuevas especies de Opiliones Laniatore. Acta Biológica Venezuelica, 17, 51-58.

Kauri, H. (1989). External ultrastructure of sensory organs in the subfamily Irumuinae (Arachnida, Opiliones, Assamiidae). Zoologica Scripta, 18 289-294.

Kury, A. B. (2014). Why does the Tricommatinae position bounce so much within Laniatores? A cladistic analysis, with description of a new family of Gonyleptoidea (Opiliones, Laniatores). Zoological Journal of the Linnean Society, 172, 11-48.

Kury, A. B., \& Villarreal, O. (2015). The prickly blade mapped: establishing homologies and a chaetotaxy for macrosetae of penis ventral plate in Gonyleptoidea (Arachnida, Opiliones, Laniatores). Zoological Journal of the Linnean Society, 174, 1-46.

Mendes, A. C. (2011). Phylogeny and taxonomic revision of Heteropachylinae (Opiliones: Laniatores: Gonyleptidae). Zoological Journal of the Linnean Society, 163, 437-483

Pérez-González, A., \& Kury, A. B. (2007). Kimulidae Pérez-González, Kury and Alonso-Zarazaga, new name. In R. Pinto-da-Rocha, G. Machado, \& G. Giribet (Eds.), Harvestmen: the biology of opiliones (pp. 207-209). Cambridge, Massachussets, and London: Harvard University Press.

Pinto-da-Rocha, R., \& Kury, A. B. (2003). Third species of Guasiniidae (Opiliones, Laniatores) with comments on familial relationships. Journal of Arachnology, 31, 394-399.

Sharma, P., \& Giribet, G. (2009). Sandokanid phylogeny based on eight molecular markers - the evolution of a Southeast Asian endemic family of Laniatores (Arachnida, Opiliones). Molecular Phylogenetics and Evolution, $52,432-447$

Sharma, P., \& Giribet, G. (2011). The evolutionary and biogeographic history of the armoured harvestmen-Laniatores phylogeny based on ten molecular markers, with the description of two new families of Opiliones (Arachnida). Invertebrate Systematics, 25, 106-142.

Ubick, D. (2007). Phalangodidae Simon, 1879. In R. Pinto-da-Rocha, G. Machado, \& G. Giribet (Eds.), Harvestmen: the biology of opiliones (pp. 217-221). Cambridge, Massachussets, and London: Harvard University Press.

Valdez-Mondragón, A., \& Francke, O. F. (2013). Two new species of ricinuleids of the genus Pseudocellus (Arachnida: Ricinulei: Ricinoididae) from southern Mexico. Zootaxa, 3635, 545-556. 